\title{
Profitabilitas pada perbankan syariah di Indonesia: Studi pengaruh faktor internal dan eksternal
}

\author{
Indri Yaumil Fadila dan Dadang Hermawan ${ }^{2}$ \\ indriyaumil17@gmail.com¹ \\ dadanghermawan@polban.ac.id²
}

1,2 Program studi Keuangan Syariah, Jurusan Akuntansi, Politeknik Negeri Bandung, Bandung, Indonesia

\begin{tabular}{ll} 
KEYWORD & ABSTRACT \\
\hline $\begin{array}{l}\text { Capital Adequacy } \\
\text { Ratio, }\end{array}$ & The purpose of this study is to find out and analyze internal \\
Non Perfoming & factors and external factors of Islamic banking that can affect \\
Finance, & the profitability of Islamic Banking both simultaneously and \\
Return On Asset, & partially. The dependent variable used in this study is income \\
Inflation & smoothing which is proxied by Profitability which is proxied \\
BI rate & by the Return On Assets (ROA), while the independent \\
& variables in this study are Capital Adequacy proxied by the \\
& Capital Adequacy Ratio (CAR), Finance Risk proxied by Non \\
& Performing Finance (NPF), Inflation, and BI Rate. This \\
& research was conducted at Sharia Commercial Banks in \\
& Indonesia for the period 2015. The population in this study is \\
& Islamic banking in Indonesia and the sample used is Sharia \\
& Commercial Banks in Indonesia, which until 2019 amounted to \\
& 14 banks. The type of data used is secondary data that is data \\
from the been published by Otoritas Jasa Keuangan. The type \\
of data used is secondary data obtained from twww.ojk.com \\
and www.bi.go.id. The analysis technique used in this study is \\
Multiple Regression analysis using the SPSS 22 program tool.
\end{tabular}




\section{Pendahuluan}

Perbankan syariah dunia mengalami perkembangan yang sangat pesat dalam waktu sepuluh tahun terakhir. Perkembangan ini terjadi dengan ditandai banyaknya negara-negara yang mendirikan bank umum syariah baik di negara yang bermayoritas muslim maupun negara lainnya seperti Amerika dan Eropa. Hal ini ditandai dengan meningkatnya aset perbankan syariah global dimana total aset mencapai mencapai USD 1,72 triliun pada tahun 2017 (Otoritas Jasa Keuangan, 2018).

Perbankan syariah yang memiliki peran sebagai lembaga keuangan Intermediary menjadikan peran ini penting dalam meningkatkan pembangunan dan menunjang perekonomian negara (Simatupang \& Franzlay, 2016). Perbankan syariah yang dalam kegiatannya menggunakan prinsip bagi hasil memberi keuntungan bagi masyarakat dan pihak bank, bank syariah juga mengedepankan aspek keadilan dalam bertransaksi, tidak melakukan kegiatan spekulatif dan mengedepankan etika. Oleh karena itu bank merupakan lembaga yang dipercayai oleh masyarakat. Semakin tinggi kepercayaan yang diberikan masyarakat terhadap bank, dapat mencerminkan baiknya kinerja suatu bank (Hijriyani \& Setiawan, 2017). Namun, perbankan syariah tidak terlepas dari permasalahannya. Salah satu permasalahannya adalah adanya praktik perbankan konvensional dalam kegiatan perbankan syariah padahal sudah jelas bahwa sistem perbankan syariah dan konvensional sangat berbeda. Di berbagai negara, perbankan syariah masih tertinggal dari perbankan konvensional.

Profitabilitas dinilai paling tepat untuk menilai kinerja keuangan suatu bank. Profitabilitas menggambarkan kemampuan perusahaan dalam mendapatkan laba melalui semua kemampuan dan sumber yang ada seperti kegiatan penjulan, kas, modal, jumlah karyawan, jumlah cabang, dan sebagainya (Harahap, 2013). Salah satu indikator yang bisa digunakan untuk mengukur kinerja profitabilitas bank adalah Return On Asset (ROA). ROA digunakan untuk mengukur efisiensi dan efektifitas perusahaan didalam menghasilkan keuntungan dengan memanfaatkan aktiva yang dimilikinya (Almunawwaroh \& Marliana, 2018).

Terdapat dua faktor yang dapat mempengaruhi besarnya profitabilitas, yaitu faktor yang berasal dari internal dan eksternal. Faktor internal yang dimaksud adalah Capital Adequacy Ratio (CAR), Net Perfoming Finance (NPF). Sedangkan faktor eksternal yang dimaksud adalah Suku Bunga BI dan Inflasi.

Penelitian mengenai pengaruh CAR terhadap profitabilitas (ROA) dilakukan oleh Apriani dan Denis (2016) yang menyimpulkan bahwa CAR berpengaruh positif terhadap Profitabilitas (ROA). Hal ini diperkuat dengan penelitian yang dilakukan oleh Sri Windarti dan Mibach F (2015). Akan tetapi berbeda dengan penelitian yang dilakukan oleh Edhi S. W dan Muh. Fakultas Ekonomi dan Bisnis Islam - UIN Sunan Gunung Djati Bandung 
Syaichu (2013) yang menyimpulkan bahwa CAR tidak berpengaruh terhadap Profitabilitas (ROA). Penelitian mengenai pengaruh NPF terhadap Profitabilitas dilakukan oleh Medina dan Rina (2016) menyatakan bahwa NPF berpengaruh negatif terhadap Profitabilitas (ROA). Namun dalam penelitian yang dilakukan Muhammad Yusuf dan Salamah (2017) menyatakan bahwa NPF tidak berpengaruh terhadap Profitabilitas (ROA). Penelitian mengenai hubungan inflasi terhadap profitabilitas (ROA) dilakukan Ayu Yanita (2013) menyebutkan bahwa Inflasi memiliki pengaruh terhadap Profitabilitas (ROA). Sedangkan penelitian yang dilakukan Toufan Aldian Syah (2018) menyebutkan bahwa Inflasi tidak memiliki pengaruh terhadap Profitabilitas (ROA). Dalam penelitian yang dilakukan oleh Luthfia Hanania (2015) menyatakan bahwa Suku Bunga BI berpengaruh terhadap Profitabilitas (ROA). Sedangkan penelitian yang dilakukan oleh Amalia Nuril (2014) menyatakan bahwa Suku Bunga BI tidak memiliki pengaruh terhadap Profitabilitas (ROA).

Setiap bank di Indonesia wajib menyediakan model mininimum sebelum melakukan kegiatan operasional. Hal ini dilakukan untuk mengatasi resiko yang akan dialami oleh bank. Bank harus memperhatikan besar modalnya sebagai penanggung resiko kerugian yang akan timbul dari penggunaan aktiva bank yang pada dasarnya berasal dari dana pihak ketiga. Dalam perhitungannya, bank menggunakan rasio kecukupan modal atau Capital Adequacy Ratio (CAR). Menurut Muhammad Capital Adequacy Ratio adalah gambaran mengenai kemampuan bank syariah dalam memenuhi kecukupan modalnya. Jika modal tersebut mampu menyerap kerugian-kerugian yang tidak dapat dihindarkan oleh suatu bank, maka bank bisa mengelola kegiatannya dengan efisien.

Profitabilitas atau keuntungan yang didapatkan oleh bank umum syariah tidak lepas dari fungsinya sebagai lembaga yang menyalurkan dana kepada masyarakat. Dalam kegiatan ini akan timbul berbagai resiko yang dihadapi. Salah satunya yaitu pembiayaan bermasalah atau Non Perfoming Financing (NPF). NPF adalah jumlah pembiayaan yang bermasalah dan kemungkinan tidak dapat ditagih, semakin besar nilai NPF maka semakin buruk kinerja bank tersebut (Muhamad, 2009). Rasio Non Performing Finance digunakan dalan bank syariah sedangkan Non Performing Loan pada bank konvensional. Karena pada bank syariah tidak mengenal adanya pinjaman namun menggunakan istilah pembiayaan. NPL mencerminkan risiko kredit, semakin kecil NPL semakin kecil pula risiko kredit yang ditanggung pihak bank (Nusantara, 2009).

Inflasi menurut Bank Indonesia diartikan sebagai kenaikan harga secara umum dan terus menerus dalam jangka waktu tertentu. Kenaikan harga dari satu atau dua barang saja tidak dapat disebut inflasi kecuali bila kenaikan itu meluas (atau mengakibatkan kenaikan harga) Fakultas Ekonomi dan Bisnis Islam - UIN Sunan Gunung Djati Bandung 
pada barang lainnya (Bank Indonesia, 2017). Friedman dalam buku Asfia Murni menyatakan inflasi selalu ada di mana saja dan merupakan suatu fenomena moneter yang menujukan adanya pertumbuhan moneter yang berlebihan dan tidak stabil. Sehingga inflasi merupakan kejadian yang menunjukkan kenaikan tingkat harga secara umum dan berlangsung secara terus-menerus.

Suku Bunga $\mathrm{Bl}$ adalah suku bunga kebijakan yang mencerminkan sikap atau stance kebijakan moneter yang ditetapkan oleh Bank Indonesia dan diumumkan kepada public (Bank Indonesia, 2017). Suku Bunga BI diumumkan oleh Dewan Gubernur Bank Indonesia setiap rapat Dewan Gubernur bulanan dan diimplementasikan pada operasi moneter yang dilakukan Bank Indonesia melalui pengelolaan likuiditas (liquidity management) di pasar uang untuk mencapai sasaran operasional kebijakan moneter (Bank Indonesia, 2017). Kenaikan Suku Bunga BI dalam industri perbankan dapat menyebabkan bunga simpanan di bank konvensional akan menjadi naik dan mengakibatkan menurunnya Dana Pihak Ketiga (DPK) pada perbankan syariah. Penyebab dari hal ini karena terjadi pemindahan dana masyarakat dari perbankan syariah ke perbankan konvensional untuk mendapatkan bunga yang lebih tinggi. Apabila Dana Pihak Ketiga (DPK) turun, maka keuntungan perbankan syariah juga akan mengalami penurunan.

\section{Kajian Literatur}

CAR dapat ditetapkan sebagai variabel yang dapat mempengaruhi profitabilitas berdasarkan pada hubungan dengan tingkat risiko yang akan dihadapi oleh bank (Pratami, 2021). Penetapan CAR dalam titik tertentu ditunjukkan agar bank mempunyai modal yang cukup untuk mengatasi kemungkinan timbulnya risiko dari suatu asset yang dikategorikan memiliki keuntungan sekaligus mengasilkan risiko. Suatu yang memiliki CAR yang besar dapat mendukung pengembangan kegiatan operasi dan keberlangsungan hidup bank serta akan mampu menanggung berbagai risiko termasuk risiko pembiayaan sehingga dapat meningkatkan profitabilitas bank. Besarnya rasio modal yang tinggi akan mampu melindungi deposan dan akan berdampak pada meningkatnya kepercayaan masyarakat terhadap bank, hingga akhirnya dapat membuat ROA menjadi meningkat (Lestari dkk, 2020).

Penelitian tentang pengaruh CAR terhadap profitabilitas ( $R O A)$ telah dilakukan oleh Apriani dan Denis (2016) yang menyimpulkan bahwa CAR berpengaruh positif terhadap Profitabilitas (ROA). Hal ini diperkuat dengan penelitian yang dilakukan oleh Sri Windarti dan Mibach F (2015). Maka, hipotesis pertama dari penelitian ini adalah sebagai berikut:

$H_{1}$ : CAR $\left(X_{1}\right)$ berpengaruh signifikan terhadap ROA $(Y)$.

Fakultas Ekonomi dan Bisnis Islam - UIN Sunan Gunung Djati Bandung 
Non Perfoming Finance (NPF) merupakan total pembiayaan bermasalah yang besar kemungkinan tidak dapat tertagih (Nur'aeni dan Setiawan, 2020), semakin besar rasio NPF menunjukan semakin buruk kinerja dari bank tersebut. Jumlah pembiayaan bermasalah yang membesar pada akhirnyaakan berpengaruh pada kemungkinan menurunnya besarkeuntungan atau laba yang didapat oleh bank tersebut. Penurunan pendapatan yang diakibatkan oleh pembiayaan bermasalah ini dapat mempengaruhi besar laba hingga akan berpengaruh pada besarnya profitabilitas atau Return on Asset (ROA) yang dihasilkan bank syariah.

Penelitian mengenai pengaruh NPF terhadap Profitabilitas dilakukan oleh Medina dan Rina (2016) menyatakan bahwa NPF berpengaruh negatif terhadap Profitabilitas (ROA). Berdasarkan penjelasan mengenai teori dan penelitian sebelumnya, maka dapat dirumuskan hipotesis bahwa Non Perfoming Finance (NPF) memiliki pengaruh negatif dan signifikan terhadap Return On Assets (ROA). Maka, hipotesis kedua dalam penelitian ini adalah sebagai berikut

$H_{2}$ : NPF $\left(X_{2}\right)$ berpengaruh signifikan terhadap ROA $(Y)$.

Dalam bidang moneter, perkembangan inflasi yang tinggi dan tidak dapat dikendalikan akan mengganggu kegiatan perbankan dalam mengalokasikan dana masyarakat (Tripuspitorini dan Setiawan, 2020). Keadaan ini diakibatkan karena tingkat inflasi yang tinggi akan membuat suku bunga riil menjadi turun. Hal demikian demikian dapat mengurangi minat masyarakat untuk minyimpan dananya dibank sehingga perkembangan dana perbankan yang didapat dari masyarakat akan menurun. Keadaan ini juga akan memberikan dampak yang buruk pata pertumbuhan ekonomi. Selain itu juga kegiatan produktif akan sangat tidak menguntungkan karena biaya yang terus bertambah besar sehingga akan merubah pandangan masyarakat yang memiliki modal untuk melakukanspekulasi, diantaranya adalah dengan menggunakan dananya untuk sektor harta tetap sepertirumah, tanah, dan bangunan. Keadaan seperti ini tentu saja dapat mempengaruhi tingkat profitabilitas bank syariah.

$H_{3}$ : Inflasi $\left(X_{3}\right)$ berpengaruh signifikan terhadap ROA $(Y)$

Menurut Tripuspitorini dan Setiawan (2020), suku bunga BI adalah suku bunga kebijakan yang mencerminkan sikap atau stancekebijakan moneter yang ditetapkan oleh Bank Indonesia dan diumumkan kepada publik. ketika suku bunga BI mengalami kenaikan, maka suku Bungan simpanan pada bank konvensional pun akan mengalami kenaikan. Hal ini menyebabkan masyarakat yang memiliki modal cenderung lebih memilih menginvestasikan dananya di bank konvensional karenatetarik pada bunga yang lebih tinggi. Maka dapat dikatakan produktifitas perbankan syariah pada sektor riil akan menjadi rendah, karena dana yang dihimpun dari masyarakat oleh bank syariah menjadi sedikit. Hal ini membuat bank syariah mengalami Fakultas Ekonomi dan Bisnis Islam - UIN Sunan Gunung Djati Bandung 
kesulitan untuk menyalurkan dananya ke sektor riil, akibatnya produktifitas bank menurun. Keadaan tersebut akan berdampak pada tingkat profitabilitas (ROA) bank syariah. Berdasarkan penjelasan mengenai teori dan penelitian sebelumnya, maka dapat dirumuskanthipotesis sebagai berikut:

$\mathrm{H}_{4}$ : Suku Bunga $\mathrm{BI}\left(\mathrm{X}_{4}\right)$ berpengaruh signifikan terhadap ROA $(\mathrm{Y})$

\section{Metode, Data, dan Analisis}

Metode penelitian yang penulis gunakan dalam penelitian ini yaitu menggunakan penelitian kuantitatif. Penelitian kuantitatif digunakan untuk menggambarkan kondisi dan fenomena dengan menggunakan angka-angka, pengolahan statistika, serta struktur dan percobaan terkontrol. Dalam penelitian ini data yang penulis gunakan adalah data yang bersifat sekunder. Data tersebut dapat diperoleh dari media elektronik. Data dalam penelitian adalah faktor internal yang didapat dari statistik perbankan syariah dari tahun 2015 sampai tahun 2019, yang dapat langsung diakses melalui situs Otoritas Jasa Keuangan (www.ojk.go.id) Untuk memperoleh data faktor eksternal didapatkan dari situs Bank Indoneisa ( $\underline{w w w . b i . g o . i d})$. Analisis Regrsi Berganda dilakukan dalan penelitian ini dan ditunjang oleh data kuantitatif yang diperoleh. Analisis regresi bergana merupakan regresi dimana terdapat variabel terikat $(Y)$ yang dapat dihubungkan dan dijelaskan oleh lebih dari satu variabel bebas $\left(X_{1}, X_{2}, X_{3}\right.$, dan $\left.X_{4}\right)$ tetapi masih menunjukkan diagram hubungan yang linier.

\section{Hasil dan Pembahasan}

\subsection{Deskripsi Sampel Penelitian}

Populasi pada penelitian ini adalah perbankan syariah yang terdiri dari Bank Umum Syariah (BUS), Unit Usaha Syariah (UUS), dan Bank Pembiayaan Rakyat Syariah (BPRS). Sedangakan sampel pada penelitian ini adalah Bank Umum Syariah yang beroprasi pada tahun penelitian.

Data dalam penelitian ini diolah dengan menggunakan Microsoft Excel 2019 dan SPSS 22.0 untuk mendapatkan hasil dari pengaruh variabel - variabel bebas (independen) yang diteliti, variabel tersebut terdiri dari Capital Adequacy Ratio (CAR), Non Performing Financing (NPF), Inflasi, dan Suku Bunga BI terhadap variabel terikat (dependen) yaitu Return On Asset (ROA). Subjek dalam penelitian ini adalah Bank Umum Syariah di Indonesia dengan menggunakan data time series (deret waktu) dari tahun 2015 sampai dengan 2019.

Fakultas Ekonomi dan Bisnis Islam - UIN Sunan Gunung Djati Bandung 


\subsection{Hasil Uji Asumsi Klasik}

Untuk menguji kelayakan model regresi yang digunakan, maka terlebih dahulu memenuhi uji asumsi klasik. Adapun uji asumsi klasik diantaranya sebagai berikut

\section{Uji Normalitas}

Pengujian ini dilakukan dengan melihat normal probability plot. Dibawah ini merupakan pengujian normalitas:

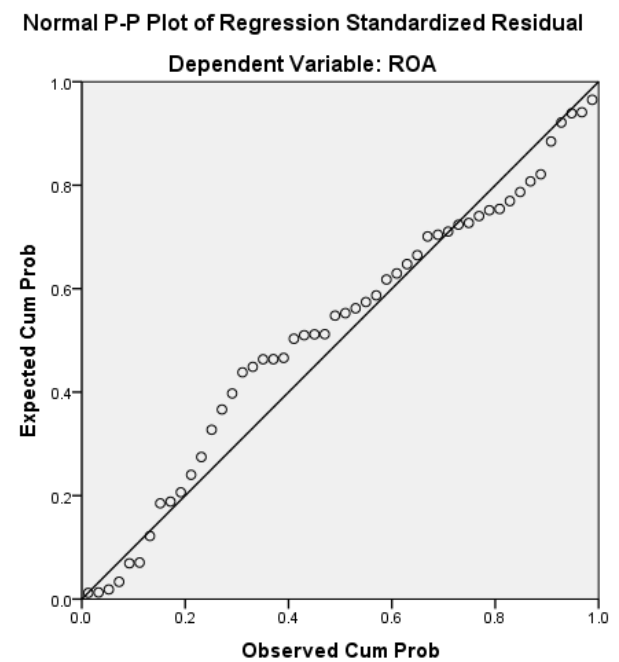

Sumber: Hasil pengolahan data SPSS 22

Gambar 7. Hasil Uji Normalitas Probability Plot

Dilihat dari gambar 7 dapat dilihat bahwa hasil data yang diteliti berdistribusi normal karena terdapat penyimpangan yang besar dari kurva dan juga dari garis normal. Dalam grafik Probability Plot tersebut membentuk garis diagonal yang lurus dengan titik-titik menyebar disekitar garis diagonal tersebut. Sehingga dengan demikian uji normalitas dapat terpenuhi.

\section{Uji Multikolinearitas}

Uji Multikolinieritas pada penelitian dapat dilakukan dilakukan dengan melihat nilai Varians Inflation Factor (VIF) dan nilai tolerance. Berikut adalah hasil pengujian multikolinearitas:

Tabel 2. Hasil Uji Multikolinearitas 


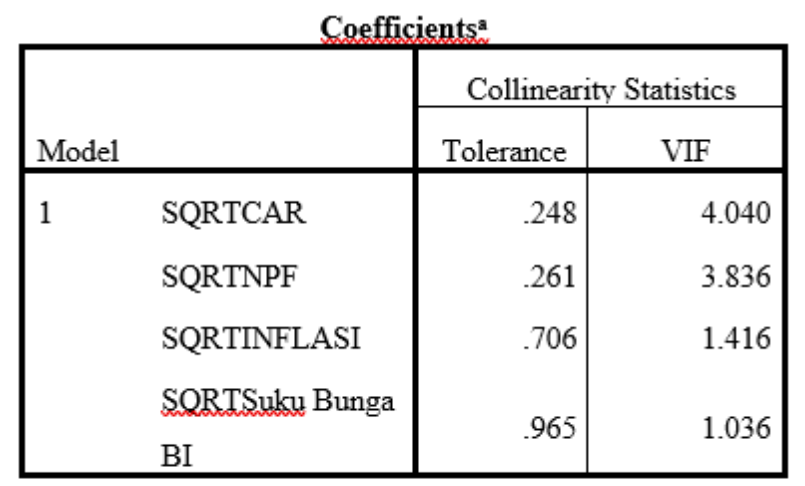

a. Dependent Variable: SQRTROA

Sumber: Hasil pengolahan data SPSS 22

Dilihat dari tabel 2 hasil uji multikolinearitas memperlihatkan bahwa pada setiap variabel tersebut tidak ada yang memilki nilai Tolerance kurang dari 0,10 serta nilai VIF pun tidak ada yang lebih dari 10. Maka dari itu dapat disimpulkan bahwa data regresi dapat digunakan karena tidak terdapat gejala multikolinearitas didalamnya.

\section{Uji Heterokedastisitas}

Uji heteroskedastisitas dalam penelitian ini dilakukan dengan grafik scatterplot. Berikut adalah hasil pengujian heterokedastisitas:

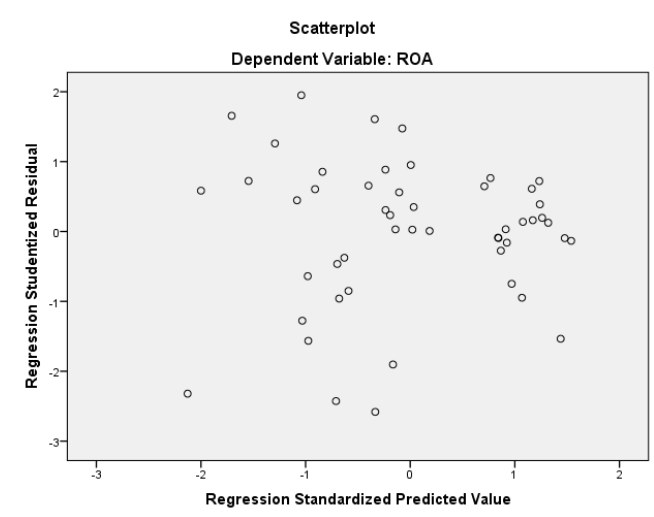

Sumber: Hasil pengolahan data SPSS 22

Gambar 8. Hasil Uji Heterokedastisitas

Berdasarkan hasil pengujian ini dapat dilihat bahwa grafik Scatterplot memperlihatkan titiktitik data menyebar di bawah dan di atas atau berada di sekitar angka o, lalu titik tersebut tidak mengumpul dalam satu tempat, dan penyebaran titik-titik data tidak membuat pola yang bergelombang melebar lalu menyempit. Maka dari itu dapat di simpulkan bahwa dalam data ini tidak terdapat geala hesteroskedastisitas.

Fakultas Ekonomi dan Bisnis Islam - UIN Sunan Gunung Djati Bandung 


\section{Uji Autokorelasi}

Dalam melakukan uji autokorelasi dapat digunalam uji Durbin-Watson (D-W). Di bawah ini merupakan hasil dari pengujian autokorelasi:

Tabel 3. Hasil Uji Autokolerasi

\begin{tabular}{|c|c|c|c|c|c|}
\hline \multicolumn{6}{|c|}{ Model Summary b } \\
\hline Model & $\mathrm{R}$ & R Square & $\begin{array}{c}\text { Adjusted R } \\
\text { Square } \\
\end{array}$ & $\begin{array}{l}\text { Std. Error of the } \\
\text { Estimate }\end{array}$ & Durbin-Watson \\
\hline 1 & $.885^{\mathrm{a}}$ & .783 & .764 & .10293 & 1.379 \\
\hline
\end{tabular}

a. Predictors: (Constant), SQRTSuku Bunga BI, SQRTNPF, SQRTINFLASI, SQRTCAR

b. Dependent Variable: SQRTROA

Sumber: Hasil pengolahan data SPSS 22

Nilai Durbin-Warson yang diperoleh sebesar 1,379. Hal ini memberikan kesimpulan bahwa tidak terjadi autokorelasi.

\subsection{Hasil Analisis Regresi Berganda}

Dalam penelitian ini, uji regresi berganda digunakan untuk menyatakan pengaruh diantara variabel bebas dengan variabel terikat. Uji regresi berganda dilakukan dengan menggunakan program SPSS versi 22. Hasil dari analisis regresi linier berganda pada penelitian ini dapat dilihat pada hasil output SPSS berikut ini:

Tabel 5. Hasil Analisis Regresi Berganda

\begin{tabular}{|c|c|c|c|c|c|c|}
\hline \multicolumn{7}{|c|}{ Coefficients ${ }^{\mathrm{a}}$} \\
\hline \multirow[b]{2}{*}{ Mod } & & \multicolumn{2}{|c|}{ Unstandardized Coefficients } & \multirow{2}{*}{$\begin{array}{c}\text { Standardized } \\
\text { Coefficients } \\
\text { Beta } \\
\end{array}$} & \multirow[b]{2}{*}{$\mathrm{T}$} & \multirow[b]{2}{*}{ Sig. } \\
\hline & & $\mathrm{B}$ & Std. Error & & & \\
\hline \multirow[t]{5}{*}{1} & (Constant) & .167 & .855 & & .196 & .846 \\
\hline & SQRTCAR & .349 & .112 & .436 & 3.122 & .003 \\
\hline & SQRTNPF & -.675 & .153 & -.601 & -4.416 & .000 \\
\hline & SQRTINFLASI & .424 & .131 & .268 & 3.246 & .002 \\
\hline & $\begin{array}{l}\text { SQRTSuku Bunga } \\
\text { BI }\end{array}$ & .003 & .076 & .003 & .045 & .964 \\
\hline
\end{tabular}

a. Dependent Variable: ROA

Sumber: Hasil pengolahan data SPSS 22

Dilihat dari hasil analisis regresi linier berganda pada tabel diatas, didapat persamaan regresi: 
SQRTROA $=0,167+0,349$ SQRTCAR $+(-0,675)$ SQRTNPF $+0,424$ SQRTINFLASI $+0,003$ SQRTBIRATE

Model persamaan regresi diatas dapat dijabarbakan sebagai berikut:

a. Konstanta sebesar 0,167 menyatakan bahwa jika CAR, NPF, BOPO, FDR, Inflasi dan Suku Bunga BI bernilai o, maka nilai ROA sebesar 0,167.

b. Koefisien regresi Capital Adequacy Ratio (CAR) sebesar 0,349. Artinya jika variabel independent lainnya tetap dan CAR mengalami kenaikan sebesar 1\% maka Return On Asset (ROA) akan mengalami kenaikan sebesar 0,349.

c. Koefisien regresi Non Performing Financing (NPF) sebesar -0,675. Artinya jika variabel independent lainnya tetap dan NPF mengalami kenaikan sebesar 1\% maka Return On Asset (ROA) akan mengalami kenaikan sebesar -0,675.

d. Koefisien regresi inflasi sebesar 0,424. Artinya jika variabel independent lainnya tetap dan inflasi mengalami kenaikan sebesar 1\% maka Return On Asset (ROA) akan mengalami kenaikan sebesari 0,424 .

e. Koefisien regresi Suku Bunga BI sebesar -0,003. Artinya jika variabel independent lainnya tetap dan Suku Bunga BI mengalami kenaikan sebesar 1\% maka Pembiayaan Bagi Hasil akan mengalami kenaikan sebesar 0,003.

\subsection{Uji Hipotesis}

Uji hipotesis yang digunakan dalam penelitian ini ada tiga, yaitu uji koefisien determinasi $\left(R^{2}\right)$, Uji F (simultan), dan Uji t (parsial).

\section{Uji t (Parsial)}

Uji t digunakan untuk mengetahui apakah variabel independen secara individu (masingmasing) berpengaruh terhadap variabel dependen. Berikut merupakan hasil pengujian secara parsial: 
Tabel 6. Hasil Uji t

\begin{tabular}{|c|c|c|c|c|c|c|}
\hline \multicolumn{7}{|c|}{ Coefficients $\mathrm{s}^{\mathrm{a}}$} \\
\hline \multirow{2}{*}{\multicolumn{2}{|c|}{ Model }} & \multicolumn{2}{|c|}{ Unstandardized Coefficients } & \multirow{2}{*}{$\begin{array}{c}\text { Standardized } \\
\text { Coefficients } \\
\text { Beta } \\
\end{array}$} & \multirow[b]{2}{*}{$\mathrm{T}$} & \multirow[b]{2}{*}{ Sig. } \\
\hline & & $\mathrm{B}$ & Std. Error & & & \\
\hline 1 & (Constant) & .167 & .855 & & .196 & .846 \\
\hline & SQRTCAR & .349 & .112 & .436 & 3.122 & .003 \\
\hline & SQRTNPF & -.675 & .153 & -.601 & -4.416 & .000 \\
\hline & SQRTINFLASI & .424 & .131 & .268 & 3.246 & .002 \\
\hline & $\begin{array}{l}\text { SQRTS Suku Bunga } \\
\text { BI }\end{array}$ & .003 & .076 & .003 & .045 & .964 \\
\hline
\end{tabular}

a. Dependent Variable: ROA

Sumber: Hasil pengolahan data SPSS 22

Pengujian secara parsial dapat dilihat pada tabel diatas. Untuk melihat pengaruh variabel bebas terhadap variabel terikat, makandapatndilihat pada nilai probabilitas dan koefisien masing-masing variabel bebas yaitu CAR, NPF, Inflasi dan Suku Bunga BI. Dapat diketahui bahwa nilai koefisien CAR yaitu sebesar 0,003. Nilai tersebut menunjukan bahwa CAR memiliki pengaruh terhadap ROA. Sehingga, berdasarkan hipotesis yang telah ditetapkan dapat disimpulkan bahwa $\mathbf{H}_{\mathbf{1}}$ diterima. Nilai koefisien NPF yaitu sebesar 0,000 . Nilai tersebut menunjukan bahwa NPF memiliki pengaruh terhadap ROA. Sehingga, berdasarkan hipotesis yang telah ditetapkan dapat disimpulkan bahwa $\mathbf{H}_{\mathbf{1}}$ diterima. Nilai koefisien inflasi yaitu sebesar 0,002. Nilai tersebut menunjukan bahwa inflasi memiliki pengaruh terhadap ROA. Sehingga, berdasarkan hipotesis yang telah ditetapkan dapat disimpulkan bahwa $\mathbf{H}_{\mathbf{1}}$ diterima. Nilai koefisien Suku Bunga BI yaitu sebesar 0,964. Nilai tersebut menunjukan bahwa Suku Bunga BI tidak memiliki pengaruh terhadap ROA. Sehingga, berdasarkan hipotesis yang telah ditetapkan dapat disimpulkan bahwa $\mathbf{H}_{\mathbf{1}}$ ditolak.

\section{Uji $f$ (Simultan)}

Uji F statistik dilakukan untuk mengetahui apakah variabel independent secara bersamasama berpengaruh terhadap variabel dependen (Ghozali, 2013). Hasil Uji F dapat dilihat pada tabel berikut ini: 
Tabel 7. Hasil Uji $f$

\begin{tabular}{|ll|r|r|r|r|r|}
\hline Model & & Sum of Squares & Df & Mean Square & F & Sig. \\
\hline 1 & Regression & 1.721 & 4 & .430 & 40.597 & $.000^{\mathrm{b}}$ \\
& Residual & .477 & 45 & .011 & & \\
& Total & 2.197 & 49 & & & \\
\hline
\end{tabular}

a. Dependent Variable: SQRTROA

b. Predictors: (Constant), SQRTSuku Bunga BI, SQRTNPF, SQRTINFLASI, SQRTCAR

Sumber: Hasil pengolahan data SPSS 22

Berdasarkan tabel diatas hasil Uji $\mathrm{F}$ menunjukkan nilai signifikansi 0,000 atau sig $0,000<0,05$, Hal ini berarti bahwa persamaan regresi yang diperoleh dapat diandalkan atau model yang digunakan sudah fix sehingga $\mathrm{H} 1$ bisa diterima bahwa terdapat pengaruh yang signifikan dari Capital Adequacy Ratio, dan Non Perfoarming Finance, Inflasi dan Suku Bunga BI terhadap Return On Asset.

\section{Uji Koefisien Determinasi atau Adjusted $R$ Square $\left(R^{2}\right)$}

Nilai koefisien determinasi pada penelitian ini dapat dilihat pada tabel berikut:

Tabel 8. Hasil Uji Koefisien Determinasi

\begin{tabular}{|l|r|r|r|r|r|}
\hline Model & \multicolumn{1}{|c|}{ Model Summary b } & \multicolumn{1}{c|}{$\begin{array}{c}\text { Adjusted R } \\
\text { Square }\end{array}$} & $\begin{array}{c}\text { Std. Error of the } \\
\text { Estimate }\end{array}$ & Durbin-Watson \\
\hline 1 & $.885^{\mathrm{a}}$ & .783 & .764 & .10293 & 1.379 \\
\hline
\end{tabular}

a. Predictors: (Constant), SQRTSuku Bunga BI, SQRTNPF, SQRTINFLASI, SQRTCAR

b. Dependent Variable: SQRTROA

Sumber: Hasil pengolahan data SPSS 22

Dapat dilihat dari hasil uji koefisien determinasi $\left(R^{2}\right)$ pada tabel 4.8 yang menunjukan besarnya koefisien determinasi variabel CAR, NPF, Inflasi dan Suku Bunga BI terhadap variabel ROA adalah 0,764. Hal ini menunjukan bahwa keempat variabel $x$ berpengaruh $76,40 \%$ terhadap variabel y, sisanya $24,60 \%$ dipengaruhi oleh variabel yang lain.

\subsection{Pembahasan Hasil Penelitian}

\section{Pengaruh Capital Adequacy Ratio (CAR) terhadap Return On Assets (ROA)}

Dari hasil penelitian menunjukan bahwa kecukupan modal yang diproksikan dengan Capital Adequacy Ratio (CAR) berpengaruh positif signifikan terhadap ROA. Arah koefisien regresi 
positif yang artinya Ketika CAR meningkat, maka ROA akan relative meningkat. Hasil ini sejalan dengan hipotesis yang dirumuskan yaitu CAR berpengaruh signifikan terhadap ROA. Bank akan semakin memiliki kemampuan yang besar untuk menanggung risiko yang dihasilkan dari aktiva maupun pembiayaan. Dengan kata lain, bank semakin memiliki kecukupan modal yang tinggi untuk menanggung risiko pinjaman macetnya, hal ini menyebabkan kinerja bank semakin baik sehingga kepercayaan masyarakat akan meningkat terhadap bank tersebut yang berujung pada meningkatnya laba.

\section{Pengaruh Non Perfoming Finance (NPF) terhadap Return On Assets (ROA)}

Dari hasil data yang dianalisis menunjukan bahwa pembiayaan bermasalah atau Non Performing Finance (NPF) memiliki pengaruh yang signifikan terhadap profitabilitas bank. Arah koefisien rgresi negatif yang menunjukan bahwa semakin besar pembiayaan bermasalah dalam pengelolaan pembiayaan oleh bank, maka akan membuat tingkat pendapatan bank akan menurun yang tercermin dalam ROA. Menurut dendawijaya salah satu akibat dariadanya Non Performing Finance yang cukup besar dalam suatu bank maka akan membuat laba menjadi berkurang sehingga akan berakibat buruk pada profitabilitas perbankan. Nilai NPF yang semakin tinggi akan mengakibatkan pihak bank perlu menyisihkan dana yang lebih besar untuk menutupi pembiayaan bermasalah yang tidak memberikan keuntungan sehingga menyebabkan profitabilitas bank akan berkurang.

\section{Pengaruh Inflasi terhadap Return On Assets (ROA)}

Dalam hasil penelitian menunjukan bahwa variabel inflasi berpengaruh signifikan terhadap ROA. Inflasi menunjukan menaiknya harga barang serta jasa pada perekonomian dalam periode waktu tertentu. Tingkat inflasi yang tinggi akan berdampak terhadap beban operasional bank yang juga akan meningkat. Selain itu inflasi juga berakibat sangat buruk bagi perekonomian karena akan membuat berkurangnya semangat untuk menabung di bank atau turunnya Marginal Propensity to Save.

\section{Pengaruh Suku Bunga BI terhadap Return On Asset (ROA)}

Dari hasil penelitian yang telah dilakukan, variabel tingkat suku bunga tidak memilikipengaruh yang signifikan terhadap ROA bank umum syariah. Dalam praktiknya, bank umum syariah menggunakan prinsip islam dalam kegiatan operasionalnya dimana bank syariah tidak menggunakan suku bunga akaren abersifat riba. Bank syaria menggunakan system bagi hasil Fakultas Ekonomi dan Bisnis Islam - UIN Sunan Gunung Djati Bandung 
sebagai ganti system suku bunga. Maka dari itu, besar atau kecilnya tingkat suku bungatentu tidak akan berpengaruh terhadap profitabilitas syariah.

\section{Conclusion and Suggestion}

Berdasarkan hasil penelitian maka dapat disimpulkan beberapa poin sebagai berikut:

a. Secara parsial tingkat kecukupan modal yang diproksikan oleh Capital Adequacy Ratio (CAR) berpengaruh signifikan terhadap Profitabilitas yang diproksikan dengan Return On Asset (ROA) dan tingkat Risiko Pembiayaan yang diproksikan oleh Non Performing Finance (NPF) berpengaruh signifikan terhadap Profitabilitas yang diproksikan dengan Return On Asset (ROA) pada Bank Umum Syariah di Indonesia.

b. Secara parsial tingkat Inflasi berpengaruh signifikan terhadap Profitabilitas yang diproksikan dengan Return On Asset (ROA) dan Suku Bunga BI berpengaruh signifikan terhadap Profitabilitas yang diproksikan dengan Return On Asset (ROA) pada Bank Umum Syariah di Indonesia.

C. Secara simultan tingkat kecukupan modal yang diproksikan oleh Capital Adequacy Ratio (CAR), Risiko Pembiayaan yang diproksikan oleh Non Perfoarming Finance (NPF), tingkat Inflasi dan Suku Bunga BI berpengaruh secara signifikan terhadap Profitabilitas yang diproksikan dengan Return On Asset (ROA) pada Bank Umum Syariah di Indonesia.

Penelitian selanjutnya diharapkan tidak hanya terpaku pada variable yang telah digunakan di penelitian ini. Peneliti dapat menambah, menguragi atau mengganti dengan variable independen yang bisa memiliki pengaruh yang lebih tinggi terhadap profitabilitas bank agar hasil penelitian dapat digunakan secara efektif dan efisien menjadi informasi yang dibutuhkan oleh subjek penelitian. Peneliti selanjutnya bisa menambah periode data ataupun menambah subjek penelitian yang digunakan sehingga hasil yang diperoleh dapat lebih relevan untuk digunakan secara luas.

\section{Reference}

Almunawwaroh, M., \& Marliana, R. (2018). Pengaruh CAR, NPF DAN FDR Terhadap Profitabilitas Bank Syariah di Indonesia. Jurnal Ekonomi dan Keuangan Syariah Vol. 2 No. 1, 1-8.

Alsharari, N. M., \& Alhmoud, T. R. (2017). The determinants of profitability in Sharia-compliant corporations: evidence from Jordan. . Journal Islamic Accounting and Business Research Vol. 10 No. 4.

Brigham, Eugene, \& Houston, J. F. (2014). Dasar-Dasar Manajemen Keuangan. Jakarta: Salemba Empat. 
Dendawijaya, L. (2009). Manajemen Perbankan. Jakarta: Ghalia Indonesia.

Ekaputri, C. (2014). Tata Kelola, Kinerja Rentabilitas, Dan Risiko Pembiayaan. Journal of Business and Banking, Vol. 4 No. 1, 94-104.

Ghozali, I. (2013). Aplikasi Analisis Multivariatite dengan program IBM SPSS 21 Update PLS Regresi. Semarang: Badan Penerbit Universitas Diponegoro.

Hanania, L. (2015). Faktor Internal Dan Eksternal Yang Mempengaruhi Profitabilitas Perbankan Syariah Dalam Jangka Pendek Dan Jangka Panjang. Perbanas Review, Vol. 1 No. 1, 151-168.

Harahap, S. S. (2013). Analisis Kritis Atas Laporan Keuangan. Jakarta: Jakarta Rajawali Press.

Hidayati, A. N. (2014). Pengaruh Inflasi, Bi Rate Dan Kurs Terhadap Profitabilitas Bank Syariah Di Indonesia. AN-NISBAH, Vol 1 No. 1, 72-97.

Hijriyani, N. Z., \& Setiawan. (2017). Analisis Profitabilitas Perbankan Syariah Di Indonesia Sebagai Dampak Dari Efisiendi Operasional. Jurnal Kajian Akuntansi, Vol 1, (2), 194-209.

Karim, A. A. (2006). Bank Islam: Analisis Fiqih dan Keuangan. Jakarta: PT Raja Grafindo Persada.

Kasmir. (2016). Analisis Laporan Keuangan. Jakarta: PT Raja Grafindo Persada.

Lestari, H. T., Setiawan, S., \& Tripuspitorini, F. A. (2020). Risk Profile, Good Corporate Governance, Earning, dan Capital dalam Memprediksi Financial Distress pada Bank Umum Syariah di Indonesia. JAE (Jurnal Akuntansi dan Ekonomi), 5(2), 100-111.

Masood, O., \& Ashraf, M. (2012). Bank specific and macroeconomic profitability determinants of Islamic banks: The case of different countries. . Qualitative Research in Financial Markets, Vol. 4, 255-268.

Mokoagow, S. W., \& Fuady, M. (2015). Faktor-Faktor yang Mempengaruhi Profitabilitas Bank Umum Syariah di Indonesia. Jurnal EBBANK, Vol.6 No.1, 33-62.

Muhamad. (2009). Modul Short Course Bank Syariah. Yogyakarta: STEI.

Murni, A. (2016). Ekonomi Makro. Bandung: PT Refika Aditama.

Nur'aeni, N, Setiawan, S. (2020). Third Party Funds and Non-Performing Financing for Mudharabah Financing in Indonesia's Sharia Banking. International Journal of Business, Economics, and Social Development, 1(4), 178-184.

Nusantara, A. B. (2009). Analisis Pengaruh NPL, CAR, LDR, dan BOPO. Semarang: FE UNDIP.

Pratami, A. F. (2021). Pengaruh CAR, LDR, dan Inflasi terhadap ROA pada Bank Umum yang Terdaftar di BEl. Indonesian Journal of Economics and Management, 1(2), 410-418.

Sahara, A. Y. (2013). Analisis Pengaruh Inflasi, Suku Bunga Bi, Dan Produk Domestik Bruto Terhadap Return On Asset (Roa) Bank Syariah Di Indonesia. Jurnal Ilmu Manajemen, Vol. 1 No. 1, 149-157.

Said, M., \& Ali, H. (2016). An analysis on the factors affecting profitability level of Sharia Banking in Indonesia. Journal Bank and Bank System, Vol. 11 No. 2, 28-36.

Saidah, S. H., \& Mauluddi, H. A. (2018). Bank Muamalat Indonesia Profitability Analys: Study Of The Effects Capital, Asset Quality, Earning And Liquidity. Jurnal Ekonomi dan Bisnis Terapan, Volume 14, No. 1, 69-81.

Santoso, S. (2012). Panduan Lengkap SPSS Versi 20. Jakarta: PT Elex Media.

Setyowati, D. H. (2019). Pengaruh Efisiensi Operasional Terhadap Return On Asset Pada Bank Umum Syariah Di Indonesia. Jurnal Masharif al-Syariah: Jurnal Ekonomi dan Perbankan Syariah Vol 4, No. 2, 39-53.

Simatupang, A., \& Franzlay, D. (2016). Capital Adequacy Ratio (CAR), Non Perfoming Finance (NPF), Efisiensi Operasional (BOPO) dan Financing to Deposit Ration (FDR) Terhadap Profitabilitas Bank Umum Syariah di Indonesia. Jurnal Aministrasi Kantor, Vol. 4, No. 2, 466-485.

Fakultas Ekonomi dan Bisnis Islam - UIN Sunan Gunung Djati Bandung 
Sugiyono. (2017). Metode Penelitian Kuantitatif, Kualitatif, dan R\&D. Bandung: Alfabeta.

Syah, T. A. (2018). Pengaruh Inflasi, Bi Rate, Npf, Dan Bopo Terhadap Profitabilitas Bank Umum Syariah Di Indonesia. Jurnal Ekonomi Islam | Islamic EconomicsJournal, Vol. 6 No. 1, 133-153.

Tripuspitorini, F. A., \& Setiawan, S. (2020). Pengaruh faktor makroekonomi terhadap pertumbuhan dana pihak ketiga pada bank umum syariah di Indonesia. Jurnal Riset Akuntansi dan Keuangan, 8(1), 121-132.

Wibisono, M. Y., \& Wahyuni, S. (2017). Pengaruh Car, Npf, Bopo, Fdr, Terhadap Roa Yang Dimediasi Oleh Nom. Jurnal Bisnis \& Manajemen, Vol. 17 No. 1, 41-62.

Wibowo, E. S., \& Syaichu, M. (2014). Analisis Pengaruh Suku Bunga,Inflasi, Car, Bopo, Npf Terhadap Profitabilitas Bank Syariah. Diponegoro Journal Of Management, Vol. 2 No. 2, 1-10.

Otoritas Jasa Keuangan. (2019). Statistik Perbankan Syariah di https://www.ojk.go.id/id/kanal/syariah/data-dan-statistik/statistik-perbankansyariah/default.aspx (diakses pada 12 November 2019).

Bank Indonesia. (2019). Laporan Inflasi (Indeks Harga Konsumen). https://www.bi.go.id/id/moneter/inflasi/data/Default.aspx (diakses pada 12 November 2019).

Bank Indonesia (2004). Peraturan Perbankan 2004. https://www.bi.go.id/id/peraturan/arsipperaturan/Contents/Perbankan-2004.aspx (diakses pada 18 November 2019).

Bank Indonesia. (2017). Surat Edaran Bank Indonesia No.9/24/DPNP/2007. https://www.bi.go.id (diakses pada 18 November 2019).

Bank Indonesia. (2004). Surat Edaran Bank Indonesia No.6/23/DPNP/2004 https://www.bi.go.id (diakses pada 18 November 2019).

Bank Indonesia. (2010). Surat Edaran Bank Indonesia No. 12/11/DPNP/2010 https://www.bi.go.id (diakses pada 19 November 2019)

Bank Indonesia. (2017). Suku Bunga Bank Indoneia. https://www.bi.go.id (diakses pada 20 November 2019).

Fakultas Ekonomi dan Bisnis Islam - UIN Sunan Gunung Djati Bandung 